\title{
Finnish School Health Education Viewed Through an Information Literacy Lens
}

\author{
Noora Hirvonen ', Tuula Nygård², Laura Palmgren-Neuvonen², Anna-Maija Huhta ', \\ and Maija-Leena Huotari ${ }^{1}$ \\ Information Studies, University of Oulu and Medical Research Centre Oulu, Oulu, \\ Finland \\ \{noora.hirvonen, anna-maija.huhta, maija- \\ leena.huotari\} doulu.fi \\ ${ }^{2}$ The Department of Educational Sciences, University of Oulu, Oulu, Finland \\ \{ tuula.nygard, laura.palmgren-neuvonen\}@oulu.fi
}

\begin{abstract}
In Finland, health education is included as an independent subject in the core curriculum for basic education where it is suggested to promote students' health literacy. In this qualitative study, we examine Finnish health education in schools through an information literacy lens. The material comprises the most recent Finnish core curricula for basic education $(2004,2014)$ and health education textbooks $(n=4)$, which were analysed with content analysis guided by theoretical conceptions of information literacy. The concept of information literacy is not used in the core curricula, but there are closely related learning objectives especially in the most recent curriculum. Textbooks cover information evaluation topics but focus less on information access and use. The study contributes to understanding the potential of information literacy promotion in school-based health education. Yet, future studies should examine health education practices to reflect how the ideas presented in the documents are implemented in practice.
\end{abstract}

Keywords: Information literacy, health education, schools.

\section{Introduction}

In Finland, health education is an independent subject in basic education and suggested to promote health literacy [1]. Health literacy includes competencies such as critical thinking and evaluation of knowledge sources [2], which in information studies are conceptualised as information literacy. These competencies are especially relevant in health contexts as health information is dynamic and found in a variety of sources [2]. In this study, we examine Finnish core curricula for basic education and health education textbooks through an information literacy lens. Although school-based health education is not built with this perspective in mind, we argue that this approach is valuable in this context. The study asks (1) how are information literacy competencies addressed in documents guiding health education in Finnish secondary education, and (2) what trends can be identified in the documents with regard to these competencies? 


\subsection{Health Education in Finnish Basic Education}

In Finland, health education became an independent school subject with specific learning objectives and evaluation criteria when it was included in the national core curriculum for basic education in 2004 [3]. The subject, called "health knowledge", is taught by a specialized teacher. In the most recent core curriculum from 2014, health literacy was taken as its learning objective $[1,2]$. Health literacy, previously viewed as basic reading and numerical skills needed in healthcare settings, is now understood to cover capabilities such as critical thinking, problem-solving, information seeking, and communication [4]. A Finnish study analysing curricula, textbooks, and other documents and a Delphi questionnaire data, showed that besides a balanced diet, analysing one's own lifestyle, and the link between physical activity and health, the ability "to source credible information online" was viewed as a key learning outcome for health education [5]. The items that ranked high by the Delphi panel but were not represented in the literature included accessing and evaluating reliable online information, assessing nutrition health claims, and sourcing reliable information [5].

Teacher work in Finland is based on the contents and learning objectives of the core curriculum and most teachers use textbooks which they choose from the supply of several publishers. Textbook use has been criticized, with claims that textbooks imply individual literacy practices and lead to surface learning. Instead, authentic and interactional learning material has been suggested [6]. Yet, textbooks can help structure lessons and facilitate scheduling, and also provide a basis for productive classroom talk [6]. Finnish health education textbooks have been examined regarding their representation of specific topics such as addictive substances [7] and sexuality [8] and from the perspectives of knowledge construction [9] and pedagogical style [9-10]. These studies indicate that the textbooks cover core curriculum themes, have a promotional rather than biomedical approach to health [9], and support constructivist ideas of learning [10-11].

\subsection{Information Literacy in the Context of Health Education}

The highly cited definition by the American Library Association (ALA) views information literacy as a set of skills to "recognize when information is needed and have the ability to locate, evaluate, and use effectively the needed information" [12]. The Association for College and Research Libraries (ACRL) [13], reflecting more recent ideas on information literacy, defines it as "the set of integrated abilities encompassing the reflective discovery of information, the understanding of how information is produced and valued, and the use of information in creating new knowledge and participating ethically in communities of learning". The Library and Information Association CILIP's [14] novel definition views information literacy as "the ability to think critically and make balanced judgements about any information we find and use. It empowers us as citizens to reach and express informed views and to engage fully with society". Moreover, it outlines contexts in which information literacy applies, including everyday life, education, and health [14]. 
Also the concept of health information literacy is used when referring to information literacy in health settings. The Medical Library Association defines health information literacy as "the set of abilities needed to: recognize a health information need; identify likely information sources and use them to retrieve relevant information; assess the quality of the information and its applicability to a specific situation; and analyze, understand, and use the information to make good health decisions.” [15, p. 294]. This definition is not far from the recent health literacy definitions, which view information seeking central to health literacy [4]. Yet, health information literacy emphasises the active role of individuals in discovering information from various sources [16] and draws from research in information studies.

Despite the differences among the definitions of information literacy, similar elements can be identified, and it has been claimed [17] that most definitions share key elements identified already in the 1989 definition by ALA [12] including information access (e.g., "ability to locate"; "reflective discovery"; "identify likely information sources"), evaluation (e.g., "ability to --- evaluate"; "understanding of how information is produced and valued"; "think critically"), and use (e.g., "use effectively", "use of information in creating new knowledge"; "use the information to make good health decisions"1). This simplified categorisation is applied in this study.

\section{Material and Methods}

The material includes texts of the most recent Finnish core curricula $(2004,2014)$ for grades 7-9 (Chapters 7.10 [3], 15.4.9 [1] Health Education, and 15.2 Transversal Competencies [1]) and of four health education textbooks. Vire published in 2008 (V08, 300 pages) and Syke, published in 2013 (S13, 399 pages) are based on the 2004 curriculum and their revised editions Vire, published in 2016 (V16, 284 pages) and Syke, published in 2017 (S17, 392 pages), on the 2014 curriculum. V08 and V16 are published by Otava Publishing Company, a major Finnish publishing house, and S13 and S17 by Edita Publishing, a Finnish publisher that also provides information and learning services. The texts were analysed with content analytic techniques in two phases. The first phase included a careful reading of the material and extraction of constellations of words (meaning units) that could be interpreted as relevant to information literacy. In the second phase, these meaning units were coded with a simplified analytical frame covering three information literacy elements: access, evaluation, and use.

\section{$3 \quad$ Findings}

\footnotetext{
${ }^{1}$ In essence, all learning can be understood as information use. This study focused on tangible uses and outcomes of information such as information creation and effects of information.
} 
Post-print of Hirvonen, N., Nygård, T., Palmgren-Neuvonen, L., Huhta, A-M. \& Huotari, M-L. (2019) Finnish School Education Viewed Through and Information Literacy Lens. In Kurbanoğlu, S., Špiranec, S., Ünal, Y., Boustany, J., Huotari, M. L., Grassian, E., Mizrachi, D. \& Roy, L. (Eds.) Information Literacy in Everyday Life. ECIL 2018. Communications in Computer and Information Science, Springer, pp. 154-165.

\subsection{General Description of the Material}

The 2004 core curriculum for basic education states that health education is based on a multidisciplinary foundation of knowledge and pursuits to promote students' competence in health, wellbeing, and safety. Health education is said to develop students' cognitive, social, emotional, functional, ethical, and emotion regulation capabilities. The starting point for instruction is an understanding of health as physical, psychological, and social capability (p. 196). Further, the curriculum describes the core contents of health education as ranging from growth and development, to health in choices in daily life, resources and coping skills, to health, society, and culture (p. 197).

In the 2014 curriculum, the text on health education has almost doubled (from approximately 800 to 1,500 words). It states that the goal of health education is to develop students' versatile health literacy including knowledge, skills, self-awareness, critical thinking, and ethical responsibility (p. 688). Objectives of instruction are divided into growth and development supporting health, factors supporting and harming health and prevention of illnesses, and health, communities, society, and culture (p. 689). Besides the independent subjects, so-called transversal competencies (T) are included: thinking and learning to learn (T1), cultural competence, interaction, and selfexpression (T2), taking care of oneself and managing daily life (T3), multiliteracy (T4), ICT competence (T5), working life competence and entrepreneurship (T6), and participation, involvement, and building a sustainable future (T7).

The textbook editions (V08 and V16; S13 and S17) cover roughly similar contents, but also significant alterations have been made. For example, in V16 an entire chapter (p. 18-23) is dedicated to health online. In S17, a chapter is included on the concept and influencers of health and subchapters (pp. 23-27) on the concept of health literacy (p. 23) and health on the media (pp. 252-258). Common to the textbooks is a combination of text types (main text, short fact texts, narratives, tables, figures, images, captions, summaries, tasks), citation of sources mostly in connection with statistics, and the inclusion of a table of contents, an index, image sources, but not a reference list. In the following subchapter, curricula and textbook texts are examined in the categories of information access, evaluation, and use.

\subsection{Information Access, Evaluation, and Use}

Information Access. The 2004 core curriculum [3] states that health education develops important skills for "the acquisition of information" (p. 196). Students should learn to utilize relevant concepts and information acquisition methods (p. 197) and have knowledge of key health care services (p. 197) including those provided by the school and municipality (p. 198). The 2014 core curriculum reads that "health education shall support the pupils' individual and communal information acquisition and construction" (p. 688). Students should learn to use concepts (p. 688), seek health services (p. 695), and search for reliable information from different sources (p. 696). The transversal competencies T1, T3, T4, and T5 include notions on information access (Table 1). 
Post-print of Hirvonen, N., Nygård, T., Palmgren-Neuvonen, L., Huhta, A-M. \& Huotari, M-L. (2019) Finnish School Education Viewed Through and Information Literacy Lens. In Kurbanoğlu, S., Špiranec, S., Ünal, Y., Boustany, J., Huotari, M. L., Grassian, E., Mizrachi, D. \& Roy, L. (Eds.) Information Literacy in Everyday Life. ECIL 2018. Communications in Computer and Information Science, Springer, pp. 154-165.

Table 1. Information access in core curricula and textbook texts

\begin{tabular}{|c|c|c|}
\hline Curricula & \multicolumn{2}{|c|}{ Textbooks } \\
\hline $\begin{array}{l}\text { 2004: Developing skills for the acquisition of } \\
\text { information; utilising concepts and information } \\
\text { acquisition methods relevant to health and disease; } \\
\text { gaining knowledge of key health care services, also } \\
\text { those provided by the school and municipality } \\
\text { 2014: Supporting individual and communal information } \\
\text { acquisition and construction; using concepts specific for } \\
\text { the field of knowledge; ways to seek health services; } \\
\text { acquiring information related to health and illness; } \\
\text { searching reliable information related to health from } \\
\text { different sources. T1 Seeking new information, looking } \\
\text { for answers and listening to others' views; reflecting on } \\
\text { personal inner knowledge; T3 Learning to find } \\
\text { information on well-being, health, and safety; T4 } \\
\text { Obtaining information in different modes, contexts, } \\
\text { situations with various tools and different types of texts } \\
\text { alone and together; T5 Seeking information diversely } \\
\text { and using sources of information in versatile ways }\end{array}$ & $\begin{array}{l}\text { V08: Students } \\
\text { guided to recognize } \\
\text { information sources; } \\
\text { sources mentioned; } \\
\text { tasks mainly based } \\
\text { on textbook content } \\
\text { V16: Notes various } \\
\text { information sources; } \\
\text { acknoweldges } \\
\text { information access } \\
\text { as a right; tasks with } \\
\text { information seeking } \\
\text { including online and } \\
\text { media sources }\end{array}$ & $\begin{array}{l}\text { S13: Sources } \\
\text { mentioned; tasks } \\
\text { mainly based on } \\
\text { textbook content } \\
\text { S17: Notes that } \\
\text { information seeking is } \\
\text { part of health literacy } \\
\text { and critical thinking; } \\
\text { acknowledges that } \\
\text { seach engines are not } \\
\text { neutral and that } \\
\text { different keywords } \\
\text { should be used; tasks } \\
\text { with various } \\
\text { information sources }\end{array}$ \\
\hline
\end{tabular}

V08 notes that there is a vast amount of information in various sources such as the Internet, magazines, television, radio, and the media and students should recognize information sources (p. 12). Possible sources are mentioned in connection with different topics, including health care services. Also, students are guided to use information in food packaging when making decisions. V16 notes that health information has come close to everyone and that it is ubiquitous. Besides the sources included in the previous edition, it notes novel public services such as electronic prescription, the medicine database, and electronic patient records (p. 269). Moreover, it acknowledges that the right to have information on sexuality is a part of young people's sexual rights (p. 153).

S13 mentions information sources, for example, by noting that in case there are concerns about one's health, these issues should be talked about with own parents, teachers, school nurse "or another adult you can trust" (p. 49). It advises that sometimes one should visit the doctor (p. 49,87) and argues that the school nurse is the one who is primarily responsible for students' health (p. 86). S17 notes that health information can be obtained from various sources, including friends (p. 23), media, and social media (p. 253-255). Moreover, it states that besides health knowledge, skills such as recognizing when to seek professional help are needed (p. 24). It describes information seeking skills as part of health literacy, critical thinking (p. 25), and media literacy (p. 254). It notes that search engines may direct one to commercial sources (p. 254) and students are instructed to seek information with different keywords (p. 275) (Table 1).

Information Evaluation. The 2004 core curriculum states that health education is to promote critical consideration of the values in health and wellbeing (p. 196). Moreover, it notes that students should learn to evaluate the meaning of environment, lifestyle, and culture and media from the perspectives of safety and health (p. 197) and should know how to critically evaluate various health information sources (p. 198). The 2014 core curriculum states that students' individual and communal information evaluation should 
Post-print of Hirvonen, N., Nygård, T., Palmgren-Neuvonen, L., Huhta, A-M. \& Huotari, M-L. (2019) Finnish School Education Viewed Through and Information Literacy Lens. In Kurbanoğlu, S., Špiranec, S., Ünal, Y., Boustany, J., Huotari, M. L., Grassian, E., Mizrachi, D. \& Roy, L. (Eds.) Information Literacy in Everyday Life. ECIL 2018. Communications in Computer and Information Science, Springer, pp. 154-165.

be supported (p. 688), including evaluation of reliability (p. 696), and the connections of media, ICT, and health (p. 696). The transversal competencies T1, T3, T4, and T5 include notions on information evaluation (Table 2).

Table 2. Information evaluation in core curricula and textbook texts

\begin{tabular}{|c|c|c|}
\hline Curricula & & extbooks \\
\hline $\begin{array}{l}\text { 2004: Promoting critical consideration } \\
\text { of values linked with health and well- } \\
\text { being; assessing the importance of the } \\
\text { media; critically assessing various } \\
\text { sources of health information } \\
\text { 2014: Individual and communal } \\
\text { information evaluation; evaluating } \\
\text { communication related to health and } \\
\text { illness; the reliability and importance of } \\
\text { communication; the reliability of health- } \\
\text { related information based on multiple } \\
\text { factors; T1 Learning to evaluate, } \\
\text { opportunities to analyse a topic critically } \\
\text { from different viewpoints; T3 } \\
\text { Examining advertising critically; T4 } \\
\text { Evaluating information in different } \\
\text { modes, contexts, situations, and with } \\
\text { various tools; T5 Practising source } \\
\text { criticism, evaluating the way } \\
\text { information is produced }\end{array}$ & $\begin{array}{l}\text { V08: Acknowledges } \\
\text { different ways to gain } \\
\text { knowledge on health; } \\
\text { notes that scientific } \\
\text { information is credible, } \\
\text { that information sources } \\
\text { can be checked; learners } \\
\text { guided to recognize the } \\
\text { role of media and } \\
\text { marketing in smoking, } \\
\text { beauty and sexual ideals, } \\
\text { and diet } \\
\text { V16: Credibility } \\
\text { evaluation criteria for } \\
\text { online health information } \\
\text { sources; media skills; } \\
\text { source criticism; tasks on } \\
\text { evaluating information }\end{array}$ & $\begin{array}{l}\text { S13: Discusses contradictory } \\
\text { information as linked with } \\
\text { substance use; the role of } \\
\text { marketing and sexual imagery in } \\
\text { building beauty standards; notes } \\
\text { thinking skills; acknowleges the } \\
\text { difference between subjective } \\
\text { and objective health; tasks on } \\
\text { interpreting statistics } \\
\text { S17: Learning to discern types of } \\
\text { knowledge; to identify and } \\
\text { critically evaluate health related } \\
\text { trends; cues to evaluate } \\
\text { credibility online; credible } \\
\text { information sources named; tasks } \\
\text { on distinguishing text types, } \\
\text { evaluating health communication } \\
\text { and information credibility }\end{array}$ \\
\hline
\end{tabular}

V08 notes the differences of measured and experienced health in scientific research (p. 10) and ways to measure mental, social, and physical health (p. 18-19). It describes scientific knowledge as trustworthy, and school health education as providing a reliable basis to fostering health and to help in understanding the significance of students' own health behaviour. It notes that it is difficult to keep up to date when, for instance, health regimens change. An example is given of the treatment of back pain, as previously, rest was recommended whereas nowadays physical activity in encouraged. It states that nothing prevents one from using his or her own reasoning and checking the source of information, and that as a consumer one has the right to ask and receive responses to questions (p. 12). Moreover, it mentions trust of one's own intuition and inner wisdom (p. 16). It discusses the role and influence of media and marketing to smoking (p. 55), sexuality (p. 152), and diet (p. 207), and advertisements' and media's influence on purchasing decisions and beauty standards (p. 207-209). V16 points out that the media serves people by providing information, but its content should be interpreted and used wisely. It notes that media skills helps in understanding media contents, acting safely and appropriately online, and helps in developing critical thinking and a healthy stance towards oneself and others (p. 19). Also, it considers source criticism (p. 19), challenges of online communication such online bullying (p. 20-21), and the way health is portrayed and discussed in the media (p. 22). It states that a critical stance should be held when considering the contents of websites and instructs students to pay attention to sites' administrator, purpose, and the time of latest update. It notes that some of the material is produced for marketing purposes, can be highly biased, and can get hacked, 
Post-print of Hirvonen, N., Nygård, T., Palmgren-Neuvonen, L., Huhta, A-M. \& Huotari, M-L. (2019) Finnish School Education Viewed Through and Information Literacy Lens. In Kurbanoğlu, S., Špiranec, S., Ünal, Y., Boustany, J., Huotari, M. L., Grassian, E., Mizrachi, D. \& Roy, L. (Eds.) Information Literacy in Everyday Life. ECIL 2018. Communications in Computer and Information Science, Springer, pp. 154-165.

and are then harnessed to present information different from the original purpose ( $\mathrm{p}$. 20). It further states that appropriate and professionally produced information is available, but there is also false information and material that is based on people's own experiences. Credible information sources are listed: the school health nurse, a doctor, information gained from health education lessons, information produced by health care organizations, helplines, and professionals' Q\&A columns (p. 22), and sites run by public sector and non-profit organizations (p. 20). It also addresses the influence of media and marketing in connection with tobacco products (p. 56), diet (p. 199) and overweight (p. 194-196; 199), mental health (p. 128), and sexuality (p. 156) (Table 2).

S13 brings up the challenge of knowing who to believe in health issues in a chapter on substance use. It notes that there is a lot of information on substances in magazines, on the Internet, music, fashion, and sports and from friends and teachers, and there are groups who speak in favour of substance use (p. 97). It discusses the role of marketing in building beauty standards (p. 152) in relation to self-image as manipulated images can create pressure on appearance and increase dissatisfaction (p. 152). It notes that sexual imagery and topics abound in media, and one can encounter sex sites when seeking information online (p. 197). In a section on the slimming business, it notes that there is a lot of hooey - marketing without a basis in reality (p. 269). Moreover, it states that reliance on authorities (others' opinions, for example) is a means for self-regulation (p. 159). S17 states that the ability to seek and use credible information requires independent critical thinking and media skills. With the help of these, one can learn to discern scientific knowledge, opinions, and advertisement from each other and to identify and critically evaluate health related trends (p. 25). It discusses the differences between experienced and measured health (p. 13-14), and notes that when seeking information on health and illnesses, it is important to know how to evaluate the credibility of information sources (p. 25). Moreover, it dedicates an entire chapter to health in the media (p. 252-258) where different health information sources and their critical evaluation are discussed in more detail. It notes, for example, that blog posts are based on opinions and can include commercial motives. When evaluating a text, students are instructed to ask, for example, what the information is based on, which sources are used, who is behind the text, and what agendas it might have. Further, each main chapter involves a skill that is to be practiced including, for example, evaluation of health communication (p. 251) and the credibility of information (p. 275) (Table 2).

Information Use. The 2004 core curriculum states that health education develops important skills for application of information (p. 196) and by through the use of concepts and information acquisition methods relevant to health and disease, promotes health (p. 197). Moreover, various sources of health information should be used (p. 198). The 2014 core curriculum emphasises support for students' individual and communal information construction and use, application of knowledge and skills related to health, safety, and illness, and means of involvement in learning environments and local communities (p. 696-697) The transversal competencies T1, T4, and T5 include notions on information use (Table 3 ). 
Post-print of Hirvonen, N., Nygård, T., Palmgren-Neuvonen, L., Huhta, A-M. \& Huotari, M-L. (2019) Finnish School Education Viewed Through and Information Literacy Lens. In Kurbanoğlu, S., Špiranec, S., Ünal, Y., Boustany, J., Huotari, M. L., Grassian, E., Mizrachi, D. \& Roy, L. (Eds.) Information Literacy in Everyday Life. ECIL 2018. Communications in Computer and Information Science, Springer, pp. 154-165.

Table 3. Information use in core curricula and textbooks texts.

\begin{tabular}{|c|c|c|}
\hline Curricula & \multicolumn{2}{|c|}{ Textbooks } \\
\hline $\begin{array}{l}\text { 2004: Important skills for application of information; } \\
\text { pupils will utilize concepts and information acquisition } \\
\text { methods relevant to health and disease, and benefit } \\
\text { from them in promoting health; using various sources of } \\
\text { health information } \\
\text { 2014: Individual and communal information use; using } \\
\text { information related to health and illness; using the } \\
\text { sources mainly in an appropriate manner; supporting } \\
\text { pupil's ability to find responsible solutions; applying } \\
\text { knowledge and skills related to health, safety, and } \\
\text { illness; supporting means of involvement in his or her } \\
\text { learning environment and local communities; T1 } \\
\text { Editing, producing, sharing information; using new } \\
\text { information as a basis for reviewing thinking; } \\
\text { formulating ideas and views; using information } \\
\text { independently and with others e.g., for problem- } \\
\text { solving; T4 Combining, modifying, producing, } \\
\text { presenting information in different modes, contexts, } \\
\text { situations with various tools; producing texts alone and } \\
\text { together; T5 Producing information diversely, using } \\
\text { ICT in information management; in exploratory and } \\
\text { creative work; in communication and networking }\end{array}$ & $\begin{array}{l}\text { V08: Notes that } \\
\text { health knowledge } \\
\text { helps make good } \\
\text { decisions; a pupil } \\
\text { can influence the } \\
\text { thoughts and } \\
\text { behavior of others } \\
\text { both locally and } \\
\text { globally; own } \\
\text { thoughts can be } \\
\text { shared trough } \\
\text { various channels } \\
\text { V16: Discussing } \\
\text { netiquette, including } \\
\text { copyright issues; } \\
\text { tasks on netiquette, } \\
\text { on creating texts and } \\
\text { thinking about how } \\
\text { to act in a situation }\end{array}$ & $\begin{array}{l}\text { S13: Notes that health } \\
\text { education increases } \\
\text { knowledge and skills } \\
\text { to promote one's } \\
\text { health; notes } \\
\text { communication skills } \\
\text { and abilities to } \\
\text { express and interpret } \\
\text { emotions; tasks on } \\
\text { creating different } \\
\text { types of texts } \\
\text { S17: Notes that } \\
\text { critical thinking and } \\
\text { media skills are } \\
\text { needed in using health } \\
\text { information; discusses } \\
\text { sharing information } \\
\text { online; tasks on } \\
\text { thinking about how to } \\
\text { act in a situation }\end{array}$ \\
\hline
\end{tabular}

V08 describes knowledge as a key element of health promotion (p. 12) and as a tool for decision-making (p. 16). It further describes health education as aiming to inspire students to know more, to present relevant questions and their own thinking about health, utilise the information obtained, in order to ease health related decision-making. It encourages students to discuss health topics at home so that others can benefit from the health knowledge obtained in school (p. 15). It discusses health as a societal issue including the ways societal actions, services, and communication influence health and the role of one's power to influence others' thoughts and behaviour (p. 15-16). New to V16 is that it touches on copyright issues (p. 19) in terms of Internet content and notes that one cannot copy text or images from online sources without permission and that source information should be mentioned if used (p. 20). Moreover, it notes the risks connected with Internet use as the content created for the Internet stays there indefinitely, spreads widely, and can be used for many purposes, also illegally (p. 21). Further, it recognises that the users of media are also producers, and media skills help create media contents independently and act safely and appropriately online (p. 19).

S13 notes that the correct information on substances and their influences builds a sound basis for one's own judgments (p. 96). Without a detailed discussion it stresses the skills of communication (p. 139) and thinking (p. 147), and abilities to express and interpret emotions (p. 155) in terms of health. S17 describes knowledge as the basis for health promotion and takes up-to-date, credible information as a precondition for healthy choices and to help understand and accept own development (p. 23). It argues, that critical thinking (p. 25) and media literacy (p. 253) are needed in using health information. Moreover, it discusses sharing information online and notes associated risks (p. 255). 


\section{Discussion and Conclusions}

The study indicates that information access, evaluation, and use are recognized in the Finnish basic education core curricula for health education and overlap with the transversal competencies of the 2014 curriculum. The notion of information literacy is not explicit in the curricula or the textbooks, but closely related learning objectives and contents can be identified. Already in the 2004 core curriculum, seeking and critical evaluation of information were addressed as skills to be included in health education. In the 2014 core curriculum, both individual and collaborative information seeking, construction, evaluation, and use are acknowledged as health education objectives in addition to the transversal competency areas such as 'multiliteracy' and 'thinking and learning to learn'. The textbooks vary in the way information literacy themes are acknowledged. Yet, some general trends can be identified. Information evaluation is more dominant than access or use, and the textbooks tend to include issues that could be characterised as relevant to media literacy rather than information literacy [see 19]. However, information literacy themes are clearly more prevalent in the recent editions.

In the textbooks, information evaluation is addressed especially in relation to media and marketing, and in the editions of 2016 and 2017, to online environments. This is in agreement with findings indicating that obtaining credible information online is viewed as a key learning outcome for health education [5]. In the more recent textbook editions, the existence of different types of health knowledge is brought up and noted that it is important to distinguish these (scientific knowledge, opinions, advertisements; measured and experienced health) from each other. This is in line with notions on information literacy in which understanding the way information is produced and valued is seen as its key element [12]. In the ACRL framework, it is noted that different authority types should be recognised and indicators of authority used to determine the credibility of sources [12].

Information access is addressed mainly by discussing the wide availability of information, mentioning appropriate information sources, and including tasks where students are guided to seek information. The more recent editions stress the importance of information seeking skills and include tasks with intertextual information seeking [18]. Previous studies show that teachers have difficulty in supporting students in information seeking [19]. Thus, besides information evaluation, attention should be paid to supporting the development of information seeking competencies and extending a critical perspective to accessing information [see 18]. Demonstrating the diversity in the conceptions of using information [20], information use in this study covered topics ranging from using information to create different types of texts and taking into account ethical and legal issues in doing so, in order to use information in decision-making and exert control on others locally and globally. A more detailed analysis of information use is beyond the scope of this article but warrants subsequent research.

Besides domain knowledge on health, health education can foster learners' information literacy. Practitioners may find the notion of media and information literacy useful in planning school-based health education as it combines the elements of media literacy and information literacy. UNESCO [21] provides pedagogical methods, curricula, and resources for teachers to integrate media and information literacy into 
Post-print of Hirvonen, N., Nygård, T., Palmgren-Neuvonen, L., Huhta, A-M. \& Huotari, M-L. (2019) Finnish School Education Viewed Through and Information Literacy Lens. In Kurbanoğlu, S., Špiranec, S., Ünal, Y., Boustany, J., Huotari, M. L., Grassian, E., Mizrachi, D. \& Roy, L. (Eds.) Information Literacy in Everyday Life. ECIL 2018. Communications in Computer and Information Science, Springer, pp. 154-165.

their pedagogical practices. In educating students to become media and information literate, teachers can respond to "their role as advocates of an informed and rational citizenry", and "to changes in their role as educators, as teaching moves away from being teacher-centred to becoming more learner-centred" [21]. This resonates well with the current Finnish core curriculum. An examination of health education materials meant for teachers and other health education textbooks available for Finnish secondary education were beyond the scope of this study. Future studies should fill in this gap. Moreover, health education practices should be examined to reflect how the ideas presented in the documents are implemented in practice. Nevertheless, the study contributes to understanding the potential of information literacy promotion in schoolbased health education.

\section{References}

1. Finnish National Board of Education: National Core Curriculum for Basic Education 2014. FNBE, Helsinki (2016)

2. Paakkari, L., Paakkari, O.: Health Literacy as a Learning Outcome in Schools. Health Educ. $112,133-152$ (2012)

3. Finnish National Board of Education: National Core Curriculum for Basic Education 2004 [In Finnish]. FNBE, Helsinki (2004)

4. Huhta, A-M., Hirvonen, N., Huotari, M-L.: Concepts Related to Health Literacy in Online Information Environments: a Systematic Review with an Emphasis on Approach to Information. In: Proceedings of the European Conference for Information Literacy 2017, pp. 460-469. Springer International Publishing, Cham, Switzerland (2018)

5. Ormshaw, M. J., Kokko, S. P., Villberg, J., Kannas, L.: The Desired Learning Outcomes of School-Based Nutrition/Physical Activity Health Education: a Health Literacy Constructed Delphi Survey of Finnish Experts. Health Educ. 116(4), 372-394 (2016)

6. Korkeamäki, R.-L., Dreher, M. J.: Early Literacy Practices and the Finnish National Core Curriculum. Journal of Curriculum Studies 43, 1. New York, Routledge (2011)

7. Carvalho, G. S., Jourdan, D., Gonçalves, A., Dantas, C., Berger, D.: Addictive Substances: Textbook Approaches from 16 Countries, J. Biol. Educ. 44(1), 26-30 (2010)

8. Honkasalo, V.: Culture and Sexuality in Finnish Health Education Textbooks. Sex Education. (2018), doi:10.1080/14681811.2018.1437030

9. Kosonen, A-L., Haapala, I., Kuurala, S., Mielonen, S., Hänninen, O., Carvalho, G. S.: Health Knowledge Construction and Pedagogical Style in Finnish Health Education Textbooks. Health Educ. 109(3), 226-241 (2009)

10. Hokkanen, S., Kosonen, A-L.: Do Finnish Home Economics and Health Education Textbooks Promote Constructivist Learning in Nutrition Education? Int. Journal Consum. Stud. 37(3), 279-285 (2013)

11. American Library Association: Presidential Committee on Information Literacy: Final Report,

(1989),

http://www.ala.org/acrl/publications/whitepapers/presidential

12. Association of College and Research Libraries: Framework for Information Literacy for Higher Education,

(2016), http://www.ala.org/acrl/standards/ilframework

13. CILIP The Library and Information Association: CILIP Definition for Information Literacy (2018), https://infolit.org.uk/ILdefinitionCILIP2018.pdf

14. Shipman, J. P., Kurtz-Rossi, S., Funk, C. J.: The Health Information Literacy Research 
Post-print of Hirvonen, N., Nygård, T., Palmgren-Neuvonen, L., Huhta, A-M. \& Huotari, M-L. (2019) Finnish School Education Viewed Through and Information Literacy Lens. In Kurbanoğlu, S., Špiranec, S., Ünal, Y., Boustany, J., Huotari, M. L., Grassian, E., Mizrachi, D. \& Roy, L. (Eds.) Information Literacy in Everyday Life ECIL 2018. Communications in Computer and Information Science, Springer, pp. 154-165.

Project. J. Med. Libr. Assoc. 97(4), 293-301 (2009)

15. Lawless, J., Toronto C. E., Grammatica, G. L.: Health Literacy and Information Literacy: a Concept Comparison. Ref. Serv. Rev. 44(2), 144-162 (2016)

16. Owusu-Ansah, E. K.: Debating Definitions of Information Literacy: Enough is Enough! Libr. Rev. 54(6), 366-374 (2005)

17. Lee, A. Y. L., So, C. Y. K.: Media Literacy and Information Literacy: Similarities and Differences. Comunicar. 42, 137-145 (2014)

18. Sundin, O.: Invisible Search: Information Literacy in the Swedish Curriculum for Compulsory Schools. Nordic Journal of Digital Literacy 10(4), 193-209 (2015)

19. Limberg, L., Alexandersson, M., Lantz-Andersson, A., Folkesson, L.: What Matters? Shaping Meaningful Learning through Teaching Information Literacy. Libri 58(2), 82-91 (2008)

20. Kari, J.: Diversity in the Conceptions of Information Use. Information Research 15(3), colis709 (2010)

21. Wilson, C., Grizzle, A., Tuazon, R., Akyempong, K., Cheung, C. K.: Media and Information Literacy Curriculum for Teachers. UNESCO, Paris (2011) 